\title{
Studies on the Effect of Different Crop Establishment Methods and Weeding Practices on Transplanted Paddy Variety CO (R) 50
}

\author{
P. Murugesan*, T. Senthivel and M. R. Nandhakumar \\ School of Agriculture and Animal Sciences, Gandhigram Rural Institute (Deemed to be \\ University), Gandhigram- 624 302, Dindigul Dist. Tamil Nadu, India \\ *Corresponding author
}

\section{A B S T R A C T}

\section{Keywords}

SRI, Establishment,

Mechanized,

Weed control,

Growth and yield

Article Info

Accepted:

10 March 2020

Available Online:

10 April 2020
An field experiment was conducted during kharif season of 2017 and Rabi season of 2018 to study the effect of crop establishment methods viz., System of Rice intensification, Machine planting, Conventional method of transplanting and weed control practices ay application of pre emergence herbicide (Metsulfuron Methyl 10\% - Chlorimuron Ethyl 10\%)10 and $20 \mathrm{~g} \mathrm{ha}^{-1}$ and, Butachlor10 $\mathrm{g} \mathrm{ha}^{-1}$ and 2.5 lit per ha ${ }^{-1}+$ three mechanized weeding at 25,35,45 DAT , hand weeding on 20 DAT, four mechanized weeding at 15,25,35,45 DAT and hand weeding twice at 20 and 40 DAT. The experiment was laid out in split plot design with a main plot of three planting methods and seven weed control practices as sub plots and were replicated twice. SRI rice registered significantly higher grain and straw yield and it was comparable with other planting methods during both the years. The lowest grain yield was observed at conventional method of planting. Among the weed management practices, SRI planting methods +pre emergence application of (Metsulfuron Methyl $10 \%$ Chlorimuron Ethyl $10 \%) 20 \mathrm{~g} \mathrm{ha}^{-1}$ cono weeding thrice registered lower weed density and dry weight which resulted in significantly higher grain yield and it was comparable with application of Butachlor 2.5 lit per ha $^{-1}+$ three mechanized weeding. The density of weeds as well as dry weight was higher in conventional method of planting. The highest weed control efficiency was recorded in SRI method of planting and pre emergence application of (Metsulfuron Methyl $10 \%$ - Chlorimuron Ethyl10\%)@20 $\mathrm{g} \mathrm{ha}^{-1}$.

\section{Introduction}

Rice (Oryza sativa L.) is one of the most important cereal crops as it is the staple food of more than $70 \%$ of the world's population. The method of establishment in rice largely affects the initial stand and uniformity. Although, transplanting in rice is considered as best for higher productivity of crop, it is not much profitable due to higher labour wages and problem of unavailability of labour during the peak period of operation. Some alternatives such as SRI and direct sowing of sprouted seeds under puddle condition must be explored to overcome these problems.

Weeds compete with crop plants for moisture, nutrients, light, space and other growth factors and these weeds appear much earlier, more sounder directs own conditions in rice. In the absence of effective control measures weeds remove considerable quantity of 
applied nutrients resulting in a significant yield loss. Manna (1991) reported a yield reduction of $25 \%$ in transplanted rice, $32 \%$ in puddle broadcast rice and $52 \%$ in direct sown upland rice due to weeds. Hence, the present experiment was conducted to find out an efficient weed management practice in relation to crop establishment methods.

The area under rice crop is decreasing year by year due to various factors such as increased cost of inputs, labour shortage and less profitability. Transplanting of rice seedlings in the traditional way is laborious, time consuming and causes drudgery. Nonavailability of labourers for transplanting at appropriate time leads to late planting, which results in poor yields. In rice, planting methods have an impact on the growth and yield, besides cost of cultivation and labour requirement.

Rice transplanting is done manually and requires about 306 man hours/ha, which is roughly 42 per cent of the total labour requirement of rice production. At transplanting time, acute labour shortage results in increased wages and delay in the operation. Manual transplanting will not be uniform and results in inadequate population. These problems necessitated the introduction of mechanized rice transplanting, to achieve timely planting and better crop stands (Hemmat and Taki, 2003). In addition, weeds are the bounding factors in agricultural production, and compete with crop plants due to their rapid growth.

Weeds decrease about 25 per cent of potential yield and pose serious threat to crop production (Jacob and Syriac, 2005). Besides, weeds compete for water, light and space creating disturbance in cultivation and maintenance with an ultimate result of yield withdrawal, reduction in quality and quantity of produce. Herbicides seem to be promising and viable options because of their immediate performance in decreasing weeds competition, easy usage, low cost and require less workforce. Agronomical manipulations such as crop establishment methods with appropriate weed management practices may offer an effective option for better control of weeds in rice, thereby enhancing rice yield. In cognizance of the above, the present study was undertaken.

\section{Materials and Methods}

Field experiment was conducted in the Farmers field of Periyanaickenpalayam, Coimbatore, Tamil Nadu. The Farm is located in the western agro climatic zone of Tamil Nadu at $11^{\circ} \mathrm{N}$ latitude, $77^{\circ} \mathrm{E}$ longitude and at an altitude of $426.72 \mathrm{~m}$ above mean sea level, to find out the effect of planting methods and weed management practices on the productivity and economics of paddy cultivation.

The experiment was replicated twice in split plot design with three crop establishment techniques viz., System of Rice Intensification (SRI- (M1)), Machine planting(M2) and Conventional planting(M3); and six weed management practices viz., S1 Pre E. Butachlor 2.5 lit per ha + Hand weeding on 45 DAT, S2- Pre.E (Metsulfuron Methyl $10 \%$ - Chlorimuron Ethyl 10\%) @ $20 \mathrm{~g}$ per ha $+\mathrm{HW}$ on 45 DAT, S3- Four mechanized weeding $(15,25,35$ and 45 DAT), S4- Pre E. Butachlor 2.5 lit per ha + three mechanized weeding (25,35 and 45 DAT), S5 - Pre.E(Metsulfuron Methyl $10 \%$ Chlorimuron Ethyl $10 \%) @ 20 \mathrm{~g}$ per ha + three mechanized weeding $(25,35$ and, 45 DAT), S6- Hand Weeding on 20 and 40 DAT and S7 - Un weeded.

The variety $\mathrm{CO}(\mathrm{R}) 50$ was used in both the seasons of the study. The experimental soil was clay loam in texture with low available 
nitrogen, medium level phosphorus and high potassium. SRI involved 14 days old single seedlings hill at $25 \times 25 \mathrm{~cm}$ and machine planting $30 \times 20 \mathrm{~cm}$ spacing, respectively in comparison to conventional method of transplanting (M3) of 21 days old 2-3 seedlings hill at $20 \mathrm{~cm} \times 10 \mathrm{~cm}$ spacing.

The seed requirement in SRI and machine planting was 8 and $10 \mathrm{~kg} \mathrm{ha}^{-1}$, respectively and $40 \mathrm{~kg} \mathrm{ha}^{-1}$ for conventional method of transplanting. Raised bed nursery for SRI planting (Baskar, 2009), tray type nursery for SRI mechanical transplanting (Bell et al., 2003) and conventional nursery for conventional transplanting $(\mathrm{CPG}, 2005)$ were prepared.

Other cultural practices and plant protection measures were followed as per recommendations of CPG, 2005. The herbicide was dissolved in 500 litres of water and sprayed with knapsack sprayer using deflector nozzle. The pre emergence herbicide was sprayed 3 days after transplanting. Data on total weed dry weight was recorded on active tillering stage by using $0.25 \mathrm{~m}$ quadrate at four places at random and analysed.

\section{Results and Discussion}

\section{Weed flora of the experiment field}

Important weed species observed in the experimental field were Echinochloa colonum, Cyperus difformis, Ecliptaalba, Marselia quadrifoliata and Ammania baccifera.

\section{Total weed dry weight}

Crop establishment methods exerted significant influence on the total weed dry weight recorded during 60 DAT. In SRI machine transplanting total weed dry weight was significantly lower, which was on par with machine transplanting. Conventional transplanting recorded higher weed dry weight (Table 1). This might be due to early suppression of weeds on one hand and better crop stand on the other hand thereby reducing weed population and dry weight of weeds.

The results are in agreement with the findings of Mohapatra et al., (2012). Weeds under conventional planting had better conditions for their early emergence, survival and growth resulting in higher weed population thereby reduced crop growth. This result is in agreement with Balasubramanian et al., (2003), who reported that occurrence of more number of weed species, higher density unit area favoured better growing conditions turning the competition in favour of weeds, thus resulted in increased weed dry weight.

Among the weed management practices, considerable reduction in total weed dry weight was recorded with conoweeding three times at 10 days interval and application of Pre. E (Metsulfuron Methyl $10 \%$ Chlorimuron Ethyl $10 \%$ ) @ 20g per ha. This might be attributed to the minimum number of total weeds with less biomass during the cropping period (Table 1). Conoweeding three times at 10 days interval recorded lesser weed dry weight due to the incorporation of weeds into soil due to frequent conoweeding. This finding is in line with the findings of Anitha and Chellappan (2011).

Crop establishment methods and weed management practices had significant interaction at all the stages of crop. SRI transplanting with conoweeding three times at 10 days interval significantly lowered the weed dry weight followed by application of Pre.E (Metsulfuron Methyl $10 \%$ Chlorimuron Ethyl 10\%) @ 20g per ha. This is in conformity with the findings of Uprety (2010), who revealed that machine planting with frequent conoweeding had encouraged 
frequent loosening of soil stimulating aerobic conditions with concomitant reduction in the density of weeds, dry matter.

\section{Grain yield}

Crop establishment methods and weed management practices had significant influence on grain yield during both the years of experimentation (Table 1). The SRI transplanting (M1) produced distinctly higher grain yield than conventional transplanting (M3).

This might be due to less crop weed competition, larger root system and crop canopy and higher microbial population, which might have facilitated the enhanced nutrient uptake, photosynthetic activity and enhanced nutrient uptake, photosynthetic activity and remobilization of photosynthates to grain resulting in higher yield attributes and yield.

This is in accordance with the findings of Hugar et al., (2009), who stated that SRI gave higher grain yield due to large root volume, strong tillers with improved yield attributes. Chandrapala et al., (2010) also reported increased grain yield with SRI, which was attributed to lesser competition, enhanced solar radiation interception, nutrients uptake and higher yield attributes. Conoweeding three times at 10 days interval starting from 25 DAT recorded higher grain yield than unweeded control (S7).

This finding is in accordance with the results of Thiyagarajan et al., (2002), who found that use of conoweeder resulted in increased yield of rice. Crop establishment methods and weed management practices had significant interaction with each other at all the crop growth stages. The SRI machine transplanting with conoweeding three times at 10 days interval starting from 25 DAT registered higher grain yield than other combinations. This might be due to larger canopy with greater root development and activity, less intra plant competition, improved remobilization of assimilates to grain.

These results are in accordance with the findings of Mohaptra et al., (2012), who reported that machine planting with mechanical weeding had encouraged profuse tillering and influenced yield attributes such as number of panicle $\mathrm{m}^{-2}$ and number grains panicle. The least grain yield was recorded under conventional planting with unweeded check (S7)

\section{Straw yield}

Significant difference with respect to straw yield due to crop establishment methods and weed management practices was evident during both the years (Table 2). The SRI transplanting (M1) resulted in significantly higher straw yield. This was mainly due to more number of tillers and increased the dry matter production. This result is in corroboration with the findings of Revathi (2009), who also reported that higher straw yield in SRI due to higher tillers and DMP.

Conoweeding three times at 10 days interval starting from 25 DAT recorded higher straw yield over all other weed management practices during both the years. However, comparable straw yield was noticed with combined application of Pre. E (Metsulfuron Methyl $10 \%$ - Chlorimuron Ethyl $10 \%$ ) @ $20 \mathrm{~g}$ per ha during both the years. Invariably, lesser straw yield was registered with unweeded control (S7) over all other weed management practices during both the years. Ramamoorthy (2004) and Mohanty and Mohanty (2010) reported that three times conoweeding had removed most of the weeds and incorporated them in to soil, responsible for loosening of top soil. 
Table.1 Effect of crop establishment methods and weed management practices on growth, yield attributes and yield of paddy during kharif 2017 and 2018

\begin{tabular}{|c|c|c|c|c|c|c|c|c|c|c|}
\hline \multirow[t]{2}{*}{ Treatment } & \multicolumn{2}{|c|}{ Plant Height (cm) } & \multicolumn{2}{|c|}{ Grains/Panicle } & \multicolumn{2}{|c|}{ Test Weight (G) } & \multicolumn{2}{|c|}{ Grain Yield kg/ha } & \multicolumn{2}{|c|}{ Straw Yield kg/ha } \\
\hline & 2017 & 2018 & 2017 & 2018 & 2017 & 2018 & 2017 & 2018 & 2017 & 2018 \\
\hline SRI & 101.50 & 121.83 & 148 & 145 & 20.05 & 19.65 & 5903.11 & 5726.01 & 15336.1 & 14876 \\
\hline Machine & 97.55 & 116.93 & 146 & 143 & 19.94 & 19.55 & 5228.71 & 5071.85 & 13650.8 & 13241.3 \\
\hline Conventional & 75.99 & 91.22 & 143 & 141 & 19.60 & 19.21 & 4203.67 & 4077.56 & 12240.8 & 11873.5 \\
\hline SEd & 0.10 & 0.12 & 0.27 & 0.26 & 0.07 & 0.07 & 31.31 & 30.37 & 189.72 & 184.03 \\
\hline $\mathrm{CD}(\mathrm{P}=0.05)$ & 0.43 & 0.51 & 1.16 & 1.13 & 0.32 & 0.31 & 134.71 & 130.67 & 816.30 & 797.81 \\
\hline \multicolumn{11}{|l|}{ Subplot } \\
\hline S1 & 90.11 & 108.13 & 146 & 143 & 19.66 & 19.27 & 5219.78 & 5063.19 & 13693.4 & 13282.6 \\
\hline S2 & 92.15 & 110.58 & 146 & 143 & 20.19 & 19.78 & 4842.30 & 4697.03 & 12939.8 & 12551.6 \\
\hline S3 & 94.94 & 113.92 & 145 & 142 & 20.16 & 19.76 & 4959.12 & 4810.34 & 13545.2 & 13138.8 \\
\hline S4 & 95.62 & 114.57 & 147 & 144 & 19.91 & 19.52 & 5643.03 & 5473.74 & 16177.7 & 15692.4 \\
\hline S5 & 95.78 & 114.94 & 149 & 146 & 20.50 & 20.09 & 5759.33 & 5586.55 & 18029 & 17488.1 \\
\hline S6 & 95.02 & 114.03 & 146 & 143 & 19.24 & 18.86 & 4789.12 & 4645.44 & 11775.6 & 11422.3 \\
\hline S7 & 78.14 & 93.76 & 141 & 138 & 19.39 & 19.00 & 4570.12 & 4433.01 & 10037.3 & 9736.2 \\
\hline SEd & 1.44 & 1.73 & 2.21 & 2.16 & 0.30 & 0.30 & 83.50 & 81.00 & 221.61 & 214.96 \\
\hline $\mathrm{CD}(\mathrm{P}=0.05)$ & 3.03 & 3.64 & 4.64 & 4.55 & 0.64 & 0.63 & 175.43 & 170.17 & 465.59 & 451.62 \\
\hline \multicolumn{11}{|l|}{ Interactions } \\
\hline SEd ( MxS) & 2.32 & 2.78 & 3.55 & 3.48 & 0.49 & 0.48 & 137.51 & 133.39 & 402.83 & 390.75 \\
\hline $\mathrm{CD}(\mathrm{P}=\mathbf{0 . 0 5})$ & 4.88 & 5.85 & 7.50 & 7.35 & 1.06 & 1.04 & 304.60 & 295.46 & 1043.06 & 1011.77 \\
\hline SEd ( SxM) & 2.5 & 3.00 & 3.82 & 3.75 & 0.53 & 0.52 & 144.63 & 140.29 & 383.83 & 372.32 \\
\hline CD $(P=0.05)$ & 5.25 & 6.30 & 8.03 & 7.87 & 1.11 & 1.08 & 303.86 & 294.74 & 806.42 & 782.23 \\
\hline
\end{tabular}


Table.2 Effect of crop establishment methods and weed management practices on Weed density, Weed dry weight and weed control efficiency of paddy during kharif 2017 and 2018

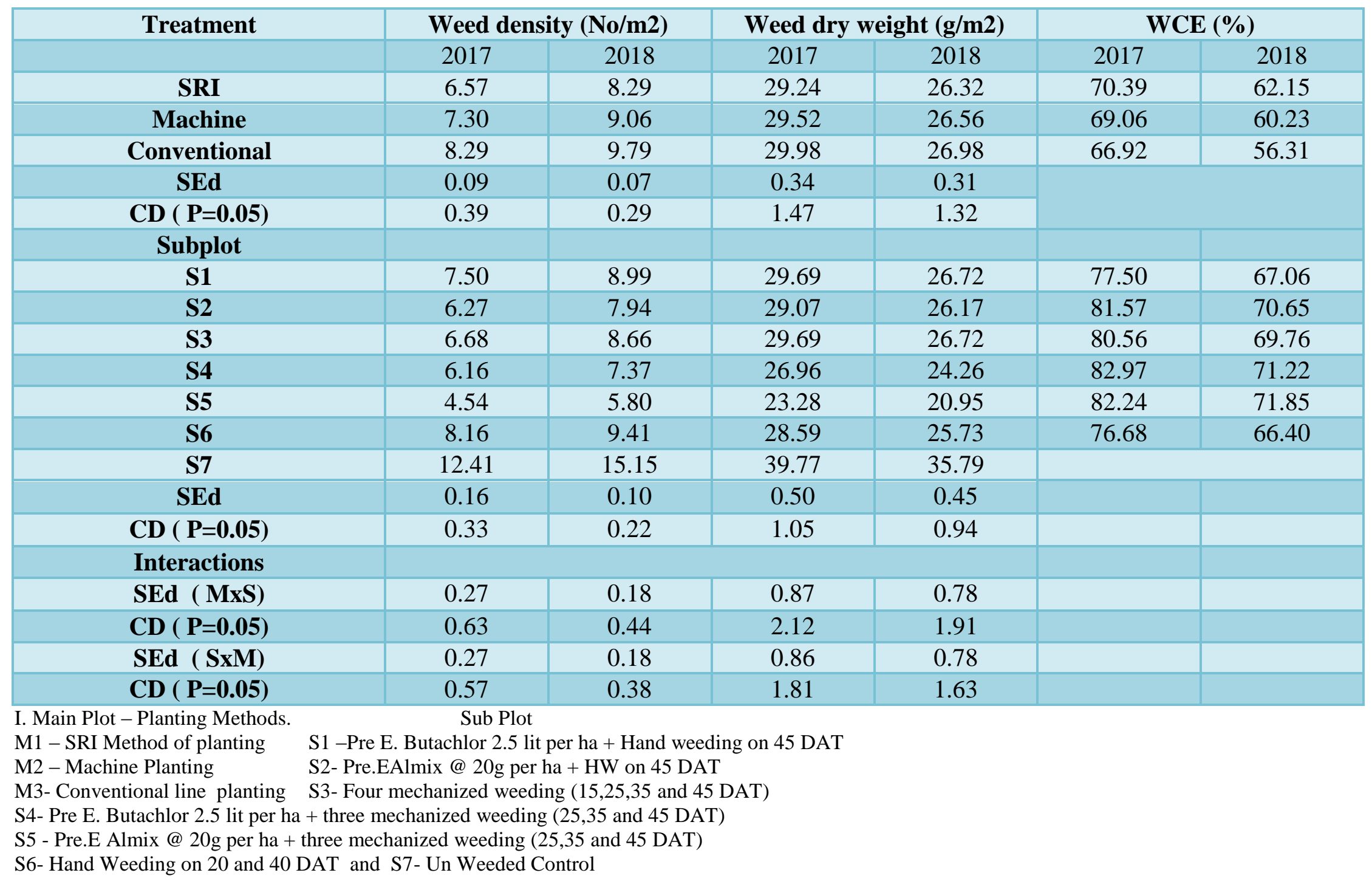


Table.3 Effect of crop establishment techniques and weed management practices on economics in rice during kharif 2017 and Rabi 2018

\begin{tabular}{|c|c|c|c|c|c|c|c|c|}
\hline Treatment & $\begin{array}{c}\text { Cost of } \\
\text { Cultivation } \\
\text { Rs/ha }\end{array}$ & $\begin{array}{c}\text { Grass } \\
\text { Income } \\
\text { Rs/ha }\end{array}$ & $\begin{array}{c}\text { Net Income } \\
\text { Rs/ha }\end{array}$ & BCR & $\begin{array}{c}\text { Cost of } \\
\text { Cultivation } \\
\text { Rs/ha }\end{array}$ & $\begin{array}{c}\text { Grass } \\
\text { Income } \\
\text { Rs/ha }\end{array}$ & $\begin{array}{l}\text { Net Income } \\
\text { Rs/ha }\end{array}$ & BCR \\
\hline & \multicolumn{4}{|c|}{2017} & \multicolumn{4}{|c|}{2018} \\
\hline SRI & 53365.25 & 131025.04 & 77659.78 & 2.46 & 58701.78 & 113991.78 & 55290.00 & 1.94 \\
\hline Machine & 53574.12 & 116189.61 & 62615.49 & 2.17 & 58931.53 & 101084.96 & 42153.43 & 1.72 \\
\hline Conventional & 53857.78 & 95943.92 & 42086.14 & 1.78 & 59243.55 & 83471.21 & 24227.65 & 1.41 \\
\hline \multicolumn{9}{|c|}{ Subplot } \\
\hline S1 & 56298.91 & 116123.08 & 59824.16 & 1.60 & 61928.81 & 101027.08 & 39098.27 & 1.27 \\
\hline $\mathbf{S 2}$ & 52440.67 & 108198.27 & 55757.60 & 1.68 & 57684.74 & 94132.50 & 36447.76 & 1.33 \\
\hline S3 & 52076.78 & 111395.60 & 59318.82 & 1.87 & 57284.46 & 96914.17 & 39629.71 & 1.48 \\
\hline S4 & 57075.24 & 128286.98 & 73013.50 & 1.87 & 60800.83 & 111609.67 & 50808.84 & 1.48 \\
\hline S5 & 55273.48 & 133966.87 & 76891.63 & 1.86 & 62782.77 & 116551.18 & 53768.41 & 1.47 \\
\hline S6 & 51128.31 & 104966.04 & 53837.73 & 1.88 & 56241.14 & 91320.46 & 35079.31 & 1.49 \\
\hline S7 & 50899.94 & 97766.46 & 46866.53 & 1.72 & 55989.93 & 85056.82 & 29066.89 & 1.36 \\
\hline
\end{tabular}


This operation had further stimulated aerobic soil condition and provided weed free environment, which enhanced growth components resulting in increased straw yield. Crop establishment methods and weed management practices had significant interaction with each other at all the stages of crop growth.

SRI machine transplanting with conoweeding three times at 10 days interval starting from 25 DAT registered higher grain yield than other combinations. This might be due to larger canopy with greater root development and activity, less intra plant competition, improved remobilization of assimilates to grain. This is corroborated with the findings of Mohapatra et al., (2012). The least grain yield was recorded under conventional planting with unweeded check (C1W6).

\section{Economics}

Crop establishment methods and weed management practices showed variations on cost of cultivation, income obtained and benefit: cost ratio (Table 3). The SRI transplanting along with conoweeding three times at 10 days interval starting from 25 DAT incurred lesser cost of cultivation and registered higher net return. This was followed by machine transplanting along with application of Pre.E (Metsulfuron Methyl 10 \% - Chlorimuron Ethyl 10 \%) @ 20g per ha. The B:C ratio was higher with SRI transplanting along with conoweeding three times at 10 days interval starting from 25 DAT during both the years because of lesser cost involved in transplanting and weeding.

Similar results were reported by Mohanty and Barik (2010), who stated that benefit cost ratio of rice transplanter was higher when compared to conventional transplanting. Further Sajitha Rani and Jayakiran (2010) stated that the net return in SRI transplanting was higher with increased B: C ratio due to higher grain yield when compared to conventional transplanting. This was mainly because of low cost incurred in transplanting and less seed requirement reduced cost of nursery preparation and less labour cost for weed control.

From the present study, it could be concluded that SRI transplanting with conoweeding three times at 10 days interval starting from 25DAT of rice will be a promising practice to increase the rice productivity and profitability. System of rice intensification and weeding with Pre.E (Metsulfuron Methyl $10 \%$ - Chlorimuron Ethyl $10 \%$ ) @ 20g per ha produced higher economic return.

\section{References}

Anitha, S. and Chellappan, M. 2011. Comparison of the system of rice intensification (SRI), recommended practices, and farmers' methods of rice (Oryza sativa L.) production in the humid tropics of Kerala, India. J. Tropical Agric., 49(1-2):64-71.

Balasubramanian, V., Ladha, J.K., Gupta, R.K., Naresh, R.K., Mehla, R.S.S., Bijay and Singh, Y. 2003. Technological option for rice in the rice-wheat system in South Asia. In: Improving the Productivity and Sustainability of Rice-Wheat Systems: Issues and Impact, pp 115-47. Ladha et al., (Eds), ASA special publication 65, ASA, CSSA, SSSA, Madison, WI.

Baskar, P. 2009. Standardisaton of nursery techniques and crop geometry for rice under system of rice intensification (SRI). M.Sc., (Ag.) Thesis, TNAU, Coimbatore, Tamil Nadu, India.

Bell, M., Balasubramanian, V. and Rickman, J. 2003. International Rice Research Institute (IRRI). In: http:// www.knowledgebank.irri.org. 
Chandrapala, A.G., Yakadri, M., Kumar, R.M. and Raj, G.B. 2010. Productivity and economics of rice (Oryza sativa) maize (Zea mays) as influenced by methods of crop establishment, $\mathrm{Zn}$ and $\mathrm{S}$ application in rice. Indian J. Agron., 55:171-176.

CPG, 2015. Crop Production Guide. Published by Directorate of Agriculture, Chennai and Tamil Nadu Agric. Univ., Coimbatore.

Hemmat A, Taki O (2003) Comparison of compaction and puddling as preplanting soil preparation for mechanized rice transplanting in very gravelly calcisols in central Iran. Soil Till Res. 70, 65-72.

Hugar, A.Y., Chandrappa, H., Jayadeva, H.M. Sathish, A. and Mallikarjun, G.B. 2009. Influence of different establishment methods on yield and economics of rice. Agric. Sci. Digest. 29: 202-205.

Jacob, D. and Syriac, E. K. 2005. Performance of transplanted scented rice (Oryza sativa L.) under different spacing and weed management regimes in southern Kerala. J. Tropical Agric., 43(1/2): 71-73.

Manna, G.B. 1991. Weed management for increasing efficiency of fertilizer. Summer Institute of Nutrition transformation and management in flooded soil-rice ecosystem. CRRI, Cuttack (Orissa) on June 1-20, pp. 391401.

Mohanty, D.K. and Mohanty, M.K. (2010).
Assessment of yield using conoweeder in SRI method of paddy cultivation. Agric. Engi. Today. 34(1): 21-24.

Mohapatra, P.C., Din, M., Parida, B.C. Patel, S.P. and Mishra, P. 2012. Effect of mechanical planting and weeding on yield, water-use efficiency and cost of production under modified system of rice intensification. Indian J. Agric Sci., 82(3): 280-283.

Ramamoorthy, K. 2004. Effect of square planting and mechanical weeding on the growth and yield of rice. M.Sc., (Ag.) Thesis, TNAU, Coimbatore, Tamil Nadu, India.

Revathi, A. 2009. Establishment techniques and weed management practices in puddled lowland rice. M.Sc., (Ag.) Thesis, TNAU, Coimbatore, Tamil Nadu, India.

Sajitha Rani, T. and K. Jayakiran. 2010. Evaluation of different planting techniques for economic feasibility in rice. Electronic Journal of Environmental, Agricultural and Food chemistry, 9 (1):150-153.

Thiyagarajan, T.M., Senthilkumar, K., Bindraban, P.S., Hengsdijk, H. and Ramasamy, S. 2002. Crop management options for increasing water productivity in rice. J. Agric. Resour. Manage., 1: 169-181.

Uprety, R. 2010. Meshing mechanization with SRI methods for rice cultivation in Nepal. 28 International Rice Research Conference, 8- 12 November 2010.

\section{How to cite this article:}

Murugesan, P., T. Senthivel and Nandhakumar, M. R. 2020. Studies on the Effect of Different Crop Establishment Methods and Weeding Practices on Transplanted Paddy Variety CO (R) 50. Int.J.Curr.Microbiol.App.Sci. 9(04): 893-901. doi: https://doi.org/10.20546/ijcmas.2020.904.107 